\title{
Understanding Snake Bite Cases Pattern Related to Volcano-Seismic Activity: An Evidence in Bondowoso, Indonesia
}

\author{
Nia Kurniawan ${ }^{1 *}$, Bagus Priambodo ${ }^{1)}$, Ahmad Muammar Kadafi ${ }^{1)}$, Agung Sih Kurnianto ${ }^{2)}$, Franky Ardiansyah ${ }^{3)}$, \\ Tri Maharani ${ }^{4)}$ \\ ${ }^{1}$ Department of Biology, University of Brawijaya \\ ${ }^{2)}$ Pascasarjana, University of Brawijaya, Jl. M.T. Haryono No.169, Malang, East Java, 65145, Indonesia. \\ 3) dr. Koesnadi Hospital, Jl. Kapten Pierre Tendean no.3, Bondowoso, East Java, 68214, Indonesia. \\ 4) East Java Health Department, Jl. A.Yani no 118, Surabaya, East Java, 60231, Indonesia. \\ e-mail: ${ }^{\left.1^{*}\right)}$ wawanunibraw@gmail.com.
}

\begin{abstract}
Bondowoso located in a valley of Raung mountain roots in East Java, Indonesia. The eruption of Mt. Raung in 2015 not only cause loss of life, but also underlining the fact of unusual Snake Bite Cases (SBC), as recorded in the dr. Koesnadi Hospital. We conducted a thorough analysis of the SBC in 2015 along with the survey on all the incident location in January to March 2016. This study represented an improvement on the population of venomous snake in the agriculture area, and reached the highest peak before the eruption. The presence of continuous vegetation at the edge of watersheds become green corridor that functioned as the movement track for snakes in order to avoid the volcano effect.
\end{abstract}

Key words : Bondowoso, Eruption, Raung, Snakebite, Green corridor

\section{INTRODUCTION}

Snakes has long been known to exhibit unusual behavior prior to seismic activities. Some researchers in many countries have been developing and observing this phenomenon for a long time [1,2]. Wang et al. [3], and Zhu and $\mathrm{Wu}$ [4] gave an example of the Haicheng earthquake of magnitude 7.3 in China was successfully predicted by the snakes abnormal behavior and people. The most unusual behavior was shown by the snakes that escaped from their haunt and froze on the ground surface. Tributsch [5], Ikeya et al. [6], and Kirschvink [7], mentioned that snakes would start to be panic, and showing some abnormal behavior that could not be explained when they recognize pre disaster signals.

In Bondowoso, an area that is vulnerable to the impact of volcano, we discovered unusual behavior of snakes during the eruption phase of Mt. Raung in 2015 [8]. Increasing population of venomous snake in agricultural area up to the urban area resulting in many Snake Bite Cases (SBC), rather than 2014. This unusual phenomenon is very interesting to be investigated, besides it to be potentially provided a new knowledge in understanding the correlation between snakes and seismic activities. Therefore, this study focused on analyzing SBC in Bondowoso by approaching all possibilities, including the relationships betweenecological condition, and SBC occurence.

\section{MATERIALS AND METHODS}

This study was conducted in Bondowoso, East Java Province, Indonesia. SBC study was conducted in two phases. First, we collected the recorded data of SBC in 2015 from the dr. Koesnadi Hospital with ethic clearance between authors and hospital management. As the central hospital, dr. Koesnadi Hospital becomes the primary referral hospital of all SBC that happened in Bondowoso. The SBC data was classified based on time, chronological case, locality and snake identification. All locations and time of SBC were divided into three stages: pre-eruption, eruption phase, and post-eruption. The results were mapped using QGIS 2.14 software to analyse the SBC pattern trend. The second phase was field observation to acknowledge snakes diversity, which was conducted on March 19-20, 2016 and July 20-21, 2016 in all the villages that reported SBC $(n=41)$ consecutively that shown most active snake period $[9,10]$. We used Visual Encounter Survey (VES) method with 100 meter line transect from 7 until 11 pm. We didn't use Time Constrained 
Studies (TCS) whereas survey conducted on different variation of time depend on species discovery. Periodically searching under the rocks, debris, humus, bushes, and twigs was done indestructively towards microhabitats [11]. Snakes identification was done by catching the snakes using bare hand, hooks, and grab sticks, and then documented with DSLR Canon 1100 D Camera. All specimens were release on same microhabitat. Taken photos were compared with literature photos for identification $[9,12,13]$. We also used vegetation analysis to reveal rice plant and plant composition on it's green corridor (1x10 m transect) [14].

\section{RESULTS AND DISCUSSION}

\section{The SBC and volcanic patterns}

Fifty-six SBC patients in the dr. Koesnadi Hospital Bondowoso were well treated and no one passed away. The survivors consisted of 40 men and 16 women, and this sex ratio represented that the cases were related with the local people's majority occupation and daily activity (Table 1). The major occupation of Bondowoso society is farmer, therefore, ricefield become the main occuring SBC compared to the other location in Bondowoso. Ricefield domination is up to $90,08 \%$ of Bondowoso total area. Thus, allow local people to be frequently made direct contact with the basking snakes on rice plants, grasses, bushes, and trees that exist in the rice field [15].

We recorded a high number of SBC before the eruption of Mt. Raung (January-May 2015). Interestingly, the SBC occurrence was in accordance with the pattern of seismic records until the end of the year (figure 1). According to the SBC pre-eruption pattern, we suggested a possibility of population changes due to local movement or drastic behavior changes. Interestingly, when volcanic activity was extremely increased, it was not followed by the increasing SBC as shown during the pre-eruption phase. The snake traffic was become more stable after they reached a secure area and avoided the eruption. This possibility strengthened by the SBC that did not occurred significantly in 2014 in Bondowoso, including in Dabasah or Petung that showed the high accident during 2015. Both of those villages are located in the Bondowoso
District, the capital of Bondowoso regency, which has a dense human population.

Earthquake and volcanic activity as natural disaster is important to be analysed due to its destructive character to a large area, even though the destructive impact could be avoided by several ways, such as mitigation system and other prediction methods. Since 1900, more than 1.000 people died on big earthquake on 24 "cones" in the world. But, several earthquakes could be predicted by early warning system, so the local community could reduce the loss of life and material damage [16].

Animals, including mammals and snakes, have the ability to accurately detect the seismic activity. They have a great sensitivity on sensing the environmental changes, both physical and chemical, such as ground tilting, humidity, electric current, and various magnetic field. They could respond quickly to $\mathrm{P}$ wave. If an animal had good sensing on $\mathrm{P}$ wave, it would lead itself to avoid behavior toward the destructive $\mathrm{S}$ wave which comes next [7]. Our observation has supported the hypothesis of seismic-escape response and indicated as form of animals mitigation from the disaster.

The seismic activity of Mt. Raung also gave a continuous induction to animals where living around the peak. The inductions could be in form of changes in temperature, $\mathrm{pH}$, and water level, which then affected the animal behavior. Even more, this conditions would trigger venomous snakes to move from the epicenter and enter Bondowoso. Therefore, according to this fact, we assume this unique phenomenon as an escape movement of venomous snakes from the Mt. Raung area to Bondowoso and other areas. The first discovery of unusual animal behavior as the indicator of pre-disaster occurrence was the presence and the movement of snakes during the hibernation period before the Haicheng earthquake in 1975. This phenomenon was impossible to be occurred if there were no strong induction that recognized by the animal senses and became a signal for them to move as their response on escaping from the death [17]. 
Table 1. Snakebite cases in terms of seismic phase. We configures the localities, survivor occupation, and snakes identification recorded in 2015. Key: Age classification $=\mathrm{A}(0-20), \mathrm{B}(21-$ 40), C(41-60), D(61-80); snake identification = V (Viperidae), E (Elapidae), C(Colubridae)

\begin{tabular}{|c|c|c|c|c|c|c|}
\hline \multirow[t]{2}{*}{ Seismic Phase } & \multicolumn{2}{|l|}{ Sex } & \multicolumn{3}{|l|}{ Location.n SBC } & \multirow[t]{2}{*}{ Occupation } \\
\hline & Male & Female & $\mathrm{V}$ & $\mathrm{E}$ & $\mathrm{C}$ & \\
\hline Before & $\mathrm{A}(3)$ & $\mathrm{A}(1)$ & Kajar.1 & Petung.1 & Petung. & Farmer(16) \\
\hline \multirow[t]{16}{*}{ Eruption } & $\mathrm{B}(5)$ & $\mathrm{B}(2)$ & Maskuning & Binakal.1 & 1 & Student(3) \\
\hline & $\mathrm{C}(8)$ & $C(1)$ & Wetan.1 & Nangkaan.1 & & Private \\
\hline & $\mathrm{D}(4)$ & $\mathrm{D}(1)$ & Bandelan.1 & Sumber & & Employees(4) \\
\hline & & & Kejawan. 1 & Tengah. 1 & & Government \\
\hline & & & Petung.1 & Wringin.1 & & Employees(1) \\
\hline & & & Sukowiryo.1 & Locare.1 & & House Wife(1) \\
\hline & & & Tenggarang. 1 & Kotakulon.1 & & \\
\hline & & & Karangmelok.1 & & & \\
\hline & & & Tamansari.1 & & & \\
\hline & & & Nangkaan 1 & & & \\
\hline & & & Dabasah.2 & & & \\
\hline & & & Patemon.1 & & & \\
\hline & & & Taman Sari.1 & & & \\
\hline & & & Maesan.1 & & & \\
\hline & & & Poncogati.1 & & & \\
\hline & & & Pecalongan1 & & & \\
\hline \multirow[t]{13}{*}{ Eruption } & $\mathrm{A}(2)$ & $\mathrm{A}(1)$ & Sukodono.1 & Pancoran.1 & & Farmer(6) \\
\hline & $\mathrm{B}(3)$ & $\mathrm{B}(1)$ & Kotakulon.1 & Kademangan.1 & & Student(4) \\
\hline & $C(3)$ & $C(3)$ & Pancoran.1 & Maskuning & & Private \\
\hline & $\mathrm{D}(3)$ & $\mathrm{D}(2)$ & Trotosari.1 & Kulon.1 & & Employees(3) \\
\hline & & & Pejaten.1 & Dabasah.1 & & Government \\
\hline & & & Penambangan.1 & Tegalampel.1 & & Employees(1) \\
\hline & & & Kejayan.1 & & & House Wife(4) \\
\hline & & & Dabasah.1 & & & \\
\hline & & & Suco Lor.1 & & & \\
\hline & & & Koncer Kidul.1 & & & \\
\hline & & & Jambeanom1 & & & \\
\hline & & & Jebung Kidul.1 & & & \\
\hline & & & Nangkaan.1 & & & \\
\hline \multirow[t]{7}{*}{ After Eruption } & $\mathrm{A}(1)$ & $\mathrm{A}(1)$ & Kotakulon.1 & Dadapan.1 & & Farmer(3) \\
\hline & $\mathrm{B}(2)$ & $\mathrm{B}(1)$ & Pancoran.1 & Gebang.1 & & Student(3) \\
\hline & $C(4)$ & $\mathrm{C}(1)$ & Wonosuko.1 & Pengarang.1 & & Private \\
\hline & $\mathrm{D}(2)$ & $\mathrm{D}(1)$ & Kajar.1 & Jebung Lor.1 & & Employees (2), \\
\hline & & & Kembang.1 & Sulek.1 & & Government \\
\hline & & & Pejaten.1 & Kademangan.1 & & Employees(1) \\
\hline & & & Tenggarang. 1 & & & House Wife(4) \\
\hline
\end{tabular}




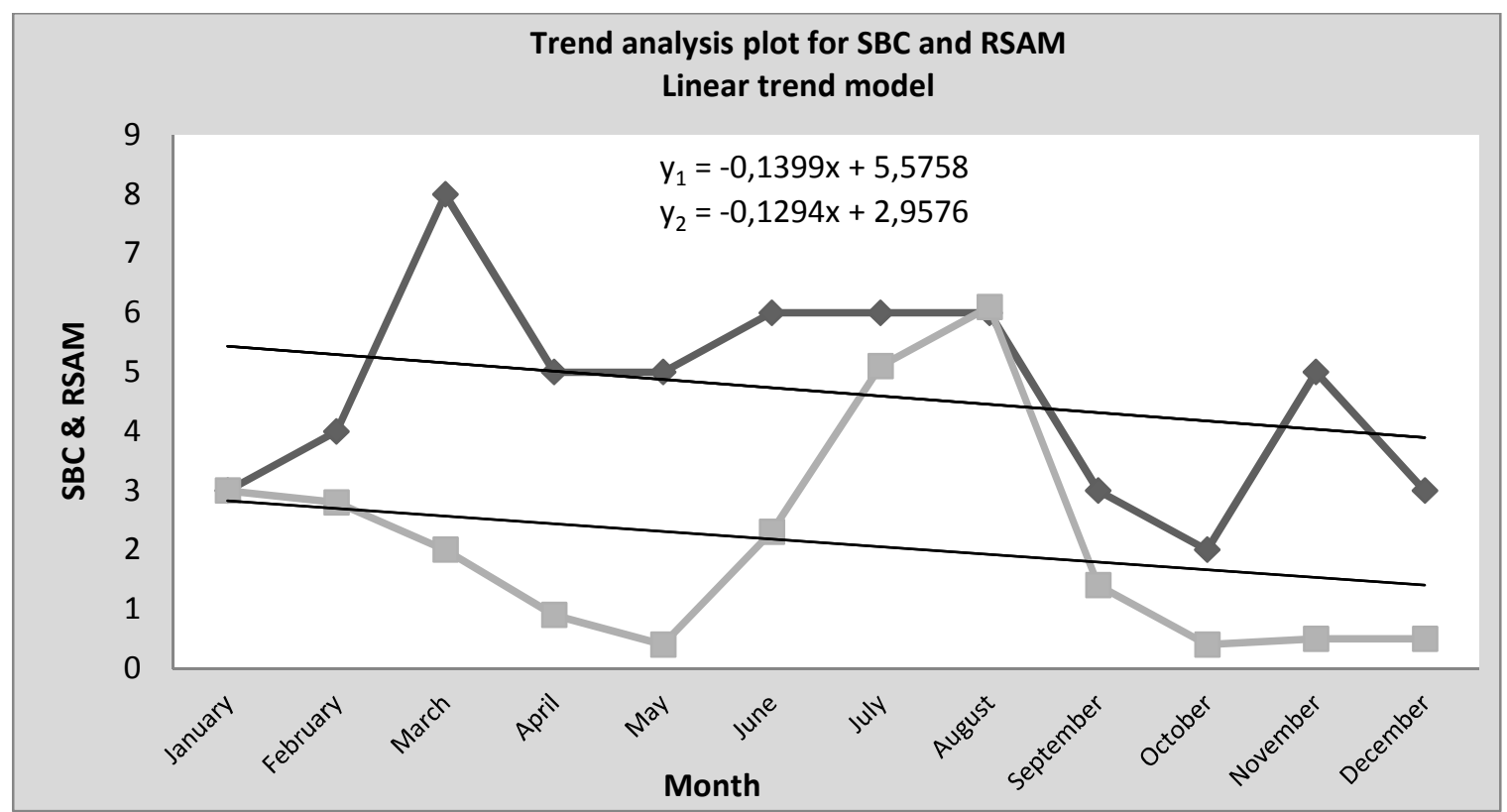

Figure 1. Snake Bite Cases (SBC) graph for time in Bondowoso. The solid-black line ilustrates snake bite cases in 2015. The SBC shows a general downward trend as shown in trendline. The grey line illustrates seismic activity in Mt. Raung based on Real-time Seismic Amplitude Measurement (RSAM) x $10^{-3}$ (configured).

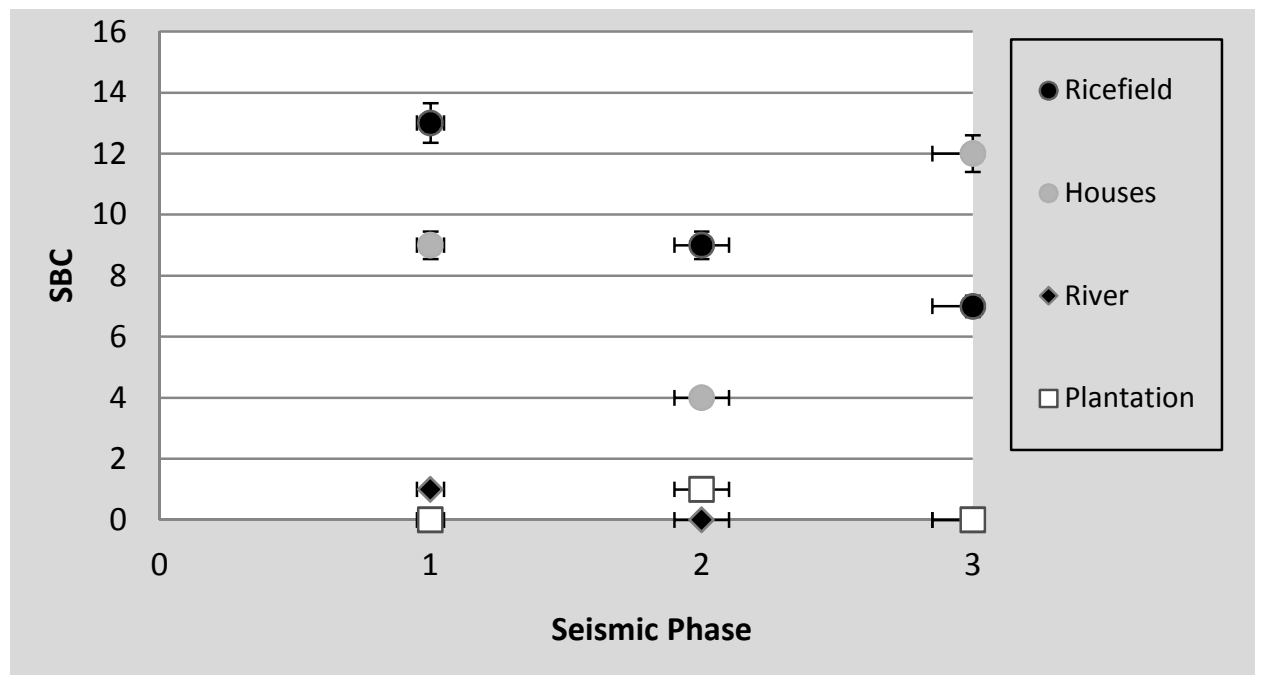

Figure 2. Snake Bite Cases (SBC) number among eruption phase. SBC calculation for each phase (x-axis) as the average number of cases on specific location. Key : 1.Before Eruption (January-May), 2.Eruption (June-August), 3.After Eruption (September-December).

We predicted that the venomous snakes moved from the peak of Mt. Raung before the eruption and reached the rice field to protect themself. Ricefield became the area with the highest SBC before the eruption, then some of the snakes were predicted to be moved to the settlement area as shown by the highest SBC number after the eruption (figure 2). The settlement area is predicted to provide an ideal hiding places for venomous snakes that is supported by various factors, such as the availability of prey [9], predator avoidance behavior [17, 18], a covered area [9], and often directly connected to the rice field. Nevertheless, people could easily distinguish snakes in residential area compared when in the rice field. Snakes could not optimize their camouflage 
ability around the residential area and resulted lower SBC [19, 20].

Snakes movement onto settlement area was occured because snakes detect some danger. As a death mitigation response, snakes will come out from soil and water, that become their natural habitat, hastily after danger detection [5]. After the eruption, some snakes were predicted to be stuck in the settlement area. We predicted that the snakes faced difficulties in finding their way back to the habitat of origin as they have to pass through some buildings or other things made by human [21].

\section{Green Corridor as a Natural Highway}

We observed the distribution of SBC that occurred in 41 villages. The record of SBC showed that all of the cases occurred near the watersheds (figure 3). Watershed is an important component for the rice field, and the water quality is strongly affected the socio-economic condition of society living near the area [22]. Therefore, most of the agricultural and the settlement area are located near the watershed. Watershed also provides water for the plants, and resulted the growth of vegetation at the edge of watershed. Furthermore, that green area is predicted to act as the green corridor between watershed located at the foothill of Mt. Raung and crossed valley (Bondowoso). Green corridor has long been recorded as the temporal track for mammals in order to obtain the needed resources [23].

Our linear survey showed an interesting fact that the venomous snakes were mostly found in the green corridor (table 2). We recorded two venomous snakes during the survey: Whitelipped Pitviper Trimeresurus alborabris
(Viperidae) and Bungarus candidus (Elapidae). While Naja sputatrix (Elapidae), as we have noted in SBC, did not found during the survey. The highest number of white-lipped Pitviper $(n=36)$ was found in Tamansari village in the relatively limited area, approximately $\pm 200 \mathrm{~m}^{2}$. More than $100 \mathrm{~m}^{2}$ vegetation was enough to become a hotspot for snakes existance [24]. White-lipped Pitviper has haemotoxic venom and its bites cause some symptoms that recorded on most of SBC in 2015. The snakes are arboreal snake that hunt other reptiles, birds, or small mammals [9]. The interesting fact is that we did not find significant number of snakes in the rice field. Our survey demonstrated a contrast role between two neighboring habitats, green corridor and ricefield. This evidence confirmed that the rice field, as the area with the highest SBC, had been influenced by the green corridor and watersheds in it.

The vegetation composition in the green corridor supported the White-lipped Pitviper as an arboreal snake. In addition, it became a temporal track for the White-lipped Pitviper and supported its camouflage capability. This fact was confirmed with the medical record showing the higher frequency of Viperidae bite that the majority of the bites were on the upper extremity. The sudden improvement on the population of Viperidae become real threats for those living in the other slopes of Mt. Raung. Therefore, it is very important to understand the possible connectivity or temporal track of snakes in order to avoid the threat. 

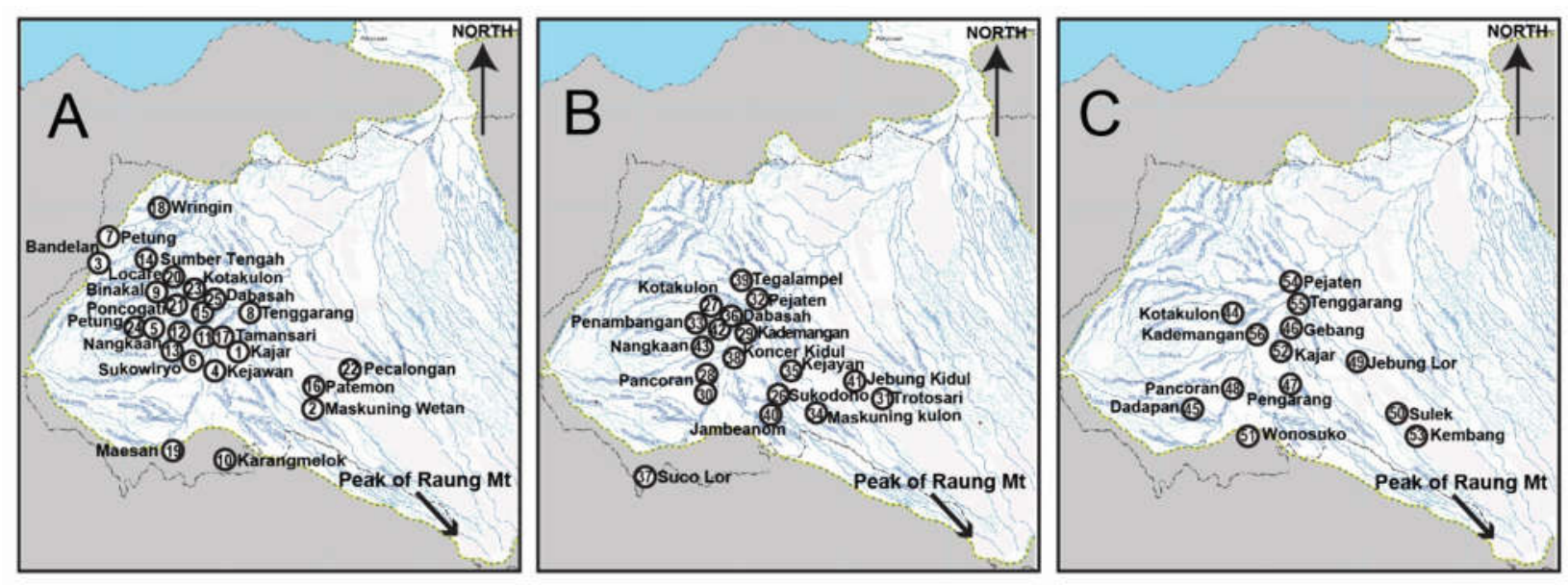

Figure 3. Snake Bite Cases (SBC) in Bondowoso $(n=56)$ based on phase : A. Before Eruption (1-25), B. Eruption Phase (26-43), C. After Eruption (44-56). Blue line shows Sampeyan river watershed. Number localities based on time chronological case. The distribution of SBC shows snakes movement and density trend pattern.

Table 2. The Composition of Green Corridor and Snakes Surveyed. Keys: Bc (Bungarus candidus), Ta (Trimeresurus alborabris).

\begin{tabular}{rlc}
\hline Classification/composition & \multicolumn{1}{c}{ Plant Species } & (n) Snakes Location \\
\hline Seedling (high 0 - 1,5 m )/20\% & Watercress Nasturtium officinale, & 2.Bc Tamansari \\
& Elephant grass Pennisetum \\
& purpureum, Rabet Passiflora sp., & \\
& Saliara Lantana camara & \\
Sapling (high $\geq 1,5-$ diameter 10 & Petung Bamboo Dendrocalamus & 2.Ta Tamansari \\
$\mathrm{cm} / 35 \%$ & asper & 3.Ta Dabasah \\
& & 2.Ta Petung \\
Pole (diameter $10-20 \mathrm{~cm}) / 20 \%$ & Petung Bamboo Dendrocalamus & 6.Ta Tamansari \\
& asper, Albasia Albazia falcataria & 2.Ta Dabasah \\
Tree (diameter $>20 \mathrm{~cm}) . / 25 \%$ & Jambu Eguinea aquea, Coconut & 26.Ta Tamansari \\
& Cocos nucifera, Banana Musa & \\
& balbisiana, Bread Fruit \\
& Artocarpus altilis, Jackfruit & \\
& Artocarpus heterophyllus, Albasia & \\
& Albazia falcataria & \\
\hline
\end{tabular}

Landscape connectivity is created some possible movement track to some certain animals. The possible tracks are usually affected by climate and vegetation. On the other hand, artificial barrier, such as street, could limit the animal's movement $[25,26]$. In this case, green corridor is lying along the river and crossing some artificial barrier, such as street and houses. This resulted a barrier for the river by the constructions (houses and bridge) above the river; while under the bridge is still covered by vegetation and functioned as green corridor. The green corridor in Bondowoso is predicted to be a suitable track for the movement of small-sized or slithered animals, including snakes. Frogs, rats, and birds also come to green corridor for protection and food searching, so snakes will assume that the dense vegetation is suitable for prey hunting. Prey existance in green corridor is linear with snakes existance, especially when the surrounding area are no longer suitable habitat, such as houses and street [24].

Traditional society in Java still lives in the slopes of volcano regardless to the risks, in order to support their socio-economic aspect supply their spiritual beliefs. They could survive and anticipate the disasters by observing the occurring of natural phenomena prior to the 
disasters, such as the birds leaving the eruption center [27]. The snake bite cases give disadvantages for the people living near or in the slopes of the volcano, although in contrary it is useful to predict the volcano eruption, so that people can prevent it or evacute earlier. By appreciating the traditional beliefs and society decision to stay in the slopes of volcano, we suggest further study related with the mapping of snake bite cases in order to prevent any possible incident. Related with the high SBC during the pre-eruption, we also suggest the procurement of antivenom in an adequate number in order to support the national mitigation system.

The presence of venomous snakes in Bondowoso before the eruption became one of the impact of Mt. Raung eruption in 2015. There was an improvement on the snake bite cases during the pre-eruption phase, and the agricultural area showed the highest cases. Present study revealed that the green corridor at the edge of watershed was used as movement track for venomous snakes in order to avoid the eruption. This sudden improvement on the snake population became a real threat for traditional society. Therefore, we suggest a better management to prevent any possible snake bite cases and procurement of antivenom as a proper mitigation system.

\section{ACKNOWLEDGEMENTS}

We show our deep gratitude to the staff of dr. Koesnadi Hospital in Bondowoso and the local government of Bondowoso Regency that have kindly supported this research.

\section{REFERENCES}

[1] Bhargava N, Katiyar VK, Sharma ML, Pradhan P. 2009. Earthquake prediction through animal behavior: A review. Indian J Biomech 159-165.

[2] Cao X. 1986. Collection of Documents on M 7.3 Earthquake (Restricted Materials). Earthquake Office of People's Government of Yingkou County, Beijing.

[3] Wang K, Chen Q, Sun S, Wang A. 2006. Predicting the 1975 Haicheng Earthquake. Bull Seismol Soc Am 96: 757-795.

[4] Zhu F, Wu G. 1982. 1975 Haicheng Earthquake. Seismological Press, Beijing.

[5] Tributsch H. 1982. When the snakes awake: Animals and earthquake prediction. MIT Press, Cambridge.
[6] Ikeya M, Furuta H, Kajiwara N, Anzai H. 1996. Ground electric field effects on rats and sparrows: Seismic anomalous animal behaviors (SAABs). Jap. J. Appl. Phys 35: 4587-4594.

[7] Kirschvink JL. 2000. Earthquake prediction by animals: Evolution and sensory perception. Bull Seismol Soc Am 90: $312-323$.

[8] Siebert L, Simkin T, Kimberly P. 2010. Volcanoes of the Worlds. Smithsonian Institution, London.

[9] Das I. 2015. A Field Guide to the Reptiles of South-East Asia. Bloomsbury Publishing Plc, London.

[10] Semiadi G, Sidik I. 2011. Karakteristik penangkapan ular di wilayah Sumatra Utara. Biota 16: 206-213.

[11] Pradhan S, Mishra D, Sahu KR. 2014. An inventory and assessment of snake diversity of gandhamardan hills range of western Oriissa, India. IJPAZ 2: 241-245.

[12] Whitaker R, Captain A. 2008. Snakes of India, the field guide. 1st Ed. Draco Books, Chengalpet.

[13] Dutta SK, Nair MV, Mohaptra PP, Mohaptra AK. 2009. Amphibians and Reptiles of Similipal Biosphere Reserve. Regional Plant Resource Center, Bhubaneswar.

[14] Foresta H, Kusworo A, Michion G, Djatmiko WA. 2000. Ketika Kebun Berupa Hutan: Agroforest Khas Indonesia Sebuah Sumbangan Masyarakat. ICRAF, Bogor.

[15] Leviton AE, Rafe MB, Cameron DS. 2014. The Dangerously Venomous Snakes of the Philippine Archipelago. California Academy of Sciences, California.

[16] Chen L, Chen X, Shao L. 2015. Method research of Earthquake Prediction and Volcano Prediction in Italy. IJG 6: 963971.

[17] Skalski GT, Gilliam GF. 2001. Functional response with predator interference: Viable alternatives to the holling type II Model. Ecol 82: 3083-3092.

[18] Peckarsky BL. 2006. Predator-Prey Interactions. Department of Zoology, University of Wisconsin, Wisconsin.

[19] Kawai N, He H. 2016. Breaking Snake Camouflage: Humans Detect Snakes More Accurately than Other Animals under Less Discernible Visual Conditions. PLoS ONE 11: e0164342. 
[20] Soares SC, Lindstrőm B, Esteves F, Ohman A. 2014. The Hidden Snake in the Grass: Superior Detection of Snakes in Challenging Attentional Conditions. PLoS ONE 9: e114724.

[21] Harper CA, Deck AL. 2014. Managing Nuisance Animals and Associated Damage around the Home. UT Extension (PB1624).

https://extension.tennessee.edu/publication s.

[22] Chen J, Lu J. 2014. Effects of Land Use, Topography and Socio-Economic Factors on River Water Quality in a Mountainous Watershed with Intensive Agricultural Production in East China. PLoS ONE 9: e102714.

[23] Jones T, Bamford AJ, Ferrol-schulte D, Hieronimo P, McWilliam N, Rovero F. 2012. Vanishing wildlife corridors and options for restoration: a case study from Tanzania.Trop Conserv Sci 5: 463-474.
[24] Langen T, Ogden KM, Schwarting LL. 2008. Predicting Hot Spots of Herpetofauna Road Mortality Along Highway Networks. J Wildl Manag 73: 104-114.

[25] Benz RA, Boyce MS, Thurfjell H, Paton DG, Musiani M, Dormann CF. 2016. Dispersal Ecology Informs Design of Large-Scale Wildlife Corridors. PLoS ONE 11: e0162989.

[26] Belote RT, Dietz MS, McRae BH, Theobald DM, McClure ML, Irwin GH. 2016. Identifying Corridors among Large Protected Areas in the United States. PLoS ONE 11: e 0154223.

[27] Bachri S, Stotter J, Monreal M, Sartohadi J. 2015. The calamity of eruptions, or an eruption of benefits? MT. Bromo humanvolcano system a case study of an openrisk perception. Nat Hazards Earth Syst Sci 15: 277-290. 